\title{
IJCIT
}

(Indonesian Journal on Computer and Information Technology) Journal Homepage: http://ejournal.bsi.ac.id/ejurnal/index.php/ijcit

\section{Perancangan Aplikasi Mobile Web Untuk Berita Acara Network Terminal Equipment Berbasis Android}

\author{
Satia Suhada ${ }^{1}$, Taufik Hidayatulloh ${ }^{2}$, Siskawati $^{3}$, Gunawan $^{4}$ \\ ${ }^{1}$ Sistem Informasi, STMIK Nusa Mandiri \\ Jakarta, Indonesia \\ Email: satia.shq@nusamandiri.ac.id \\ ${ }^{2,3}$ Sistem Informasi Kampus Kota Sukabumi, Universitas Bina Sarana Informatika \\ Sukabumi, Jawa Barat, Indonesia \\ Email: taufik.tho@bsi.ac.id ${ }^{2}$, siskawati2002@gmail.com³ \\ ${ }^{4}$ IImu Komputer Kampus Kota Sukabumi, Universitas Bina Sarana Informatika \\ Sukabumi, Jawa Barat, Indonesia \\ Email: gunawan.gnz@bsi.ac.id
}

\begin{abstract}
A B S T R A K
Kecepatan tanggapan terhadap pengaduan pelanggan sangat penting untuk segera diproses, mengingat pelanggan adalah salah satu asset bagi Telkom Akses. Salah satu permasalahan yang ada saat ini yaitu dalam pengolahan data berita acara Instalasi dan Pencabutan NTE (Network Terminal Equipment) yang masih belum terkomputerisasi dan masih berupa arsip. Hal ini mengakibatkan kurang efektif dan efesien dalam pembuatan laporan dan pencarian data. Dengan pemanfaatan suatu sistem yang berbasis mobile dalam proses laporan NTE dan berbasis web dalam pengelolaan laporannya ini, akan memudahkan teknisi dalam pembuatan laporan tanpa harus datang ke bagian admin dan pelaporan berita acara bisa lebih cepat, efektif dan efisien.
\end{abstract}

Katakunci: aplikasi mobile, berita acara, NTE

\begin{abstract}
A B STRACTS
The speed of responses to customer complaints is very important to be processed immediately, considering the customer is one of the assets for Telkom access. One of the problems that exist today is in data processing News Installation and Removal of NTE (Network Terminal Equipment) which is still not computerized and still in the form of archives. This resulted in less effective and efficient in making reports and search data. With the utilization of a mobile-based system in the NTE and web-based reporting process in the management of this report, it will make it easier for technicians in making reports without having come to the admin section and reporting the news can be more fast, effective and efficient.
\end{abstract}

Keywords: aplicatioan, mobile, news, NTE 


\section{PENDAHULUAN}

Teknologi komunikasi serta kecepatan pengiriman informasi merupakan salah satu pemanfaatan penggunaan teknologi informasi pada saat ini (Arfida, Amnah, \& Wibowo, 2018). Dampak positif dari perkembangan teknologi informasi dan komunikasi tidak bisa terlepas dari perkembangan teknologi Mobile Smartphone dan optimalisasi penggunaanya. Tidak dapat kita pungkiri, kemudahan dan kecepatan dalam mendapatkan informasi yang kita butuhkan saat ini berkat adanya Smartphone (Agustina, Suprianto, \& Muslimin, 2017).

Teknologi mobile pada saat ini tidak hanya dipergunakan untuk komunikasi saja. Aplikasi mobile khususnya Android telah berkembang begitu pesat dikarenakan semakin banyaknya pengembang dari aplikasi Android (Nur'Ainun, Hartono, \& Jimmy, 2017).

Aplikasi yang dirancang tidak hanya digunakan oleh perorangan, namun banyak perusahaan mulai membuat aplikasi untuk kebutuhan internal mereka sendiri.

PT. Telkom Akses merupakan anak perusahaan dari PT. Telekomunikasi Indonesia, Tbk (Telkom) yang sepenuhnya sahamnya dimiliki oleh Telkom. PT. Telkom Akses bergerak dalam bidang bisnis penyedia layanan konstruksi dan pengelolaan infrastruktur jaringan. Kecepatan teknologi informasi untuk tanggapan terhadap pengaduan pelanggan sangat penting untuk segera ditindaklanjuti, mengingat pelanggan merupakan salah satu aset penting bagi PT. Telkom Akses. Perkembangan teknologi informasi belum sepenuhnya dimanfaatkan oleh PT. Telkom Akses khususnya pada bagian pengolahan data berita acara instalasi dan pencabutan NTE (Network Terminal Equipment). Pada bagian ini masih menggunakan kertas arsip untuk pengolahan datanya. Oleh karena itu, untuk kecepatan pengiriman data NTE aplikasi mobile Android akan digunakan oleh teknisi di lapangan, sedangkan aplikasi web digunakan untuk pengelolaan serta monitor data NTE yang telah terpasang atau sudah dicabut.

Teknologi berbasis mobile semakin meningkat. Beberapa penelitian sebelumnya yang menerapkan teknologi aplikasi berbasis mobile, diantaranya dalam mendiagnosa penyakit diare pada balita, aplikasi mobile digunakan agar mendapat informasi yang lebih cepat dan fleksibel (Munggaran \& Hidayatulloh, 2015), aplikasi mobile digunakan pula untuk mendukung kinerja para pegawai di instansi pemerintahan (Irsan, 2015), juga digunakan dalam penanganan kondisi darurat guna mengingkatkan respon cepat petugas keamanan kepada masyarakat (Alam \& Herman, 2018), aplikasi android juga dterapkan pada sitem pakar hukum pidana pencurian (Wibowo, Afrian, Bahri, Hidayatulloh, \& Wajhillah, 2018) kemudian selain itu penggunaan aplikasi mobile juga diterapkan untuk multimedia interaktif pembelajaran siswa di SMK berbasis mobile learning (Simalango, Huda, \& Dwiyani, 2018).

Pada penelitian kali ini aplikasi mobile akan dipergunakan oleh teknisi di lapangan untuk pengiriman data NTE, setelah itu laporan akan secara langsung terintegrasi pada aplikasi web di kantor PT. Telkom Akses.

\section{METODE PENELITIAN}

Bahan yang digunakan pada penelitian ini merupakan data-data dari PT. Telkom Akses yang terdiri dari:

a. Data mengenai sejarah, struktur organisasi beserta fungsi dari PT. Telkom Akses

b. Data mengenai proses bisnis sistem berjalan pengelolaan berita acara pemasangan dan pencabutan NTE (Network Terminal Equipment) yang ada pada PT. Telkom Akses. Adapun bahan penelitian lainnya yang digunakan yaitu: paper, e-journal dan dokumentasi lainnya yang didapat dari internet.

Untuk mendukung penelitian ini, pengumpulan data dilakukan dengan menggunakan teknik sebagai berikut:

a. Observasi

Pengamatan dilakukan di PT. Telkom Akses Sukabumi untuk melihat secara langsung sekaligus mengamati sistem pelaporan NTE.

b. Wawancara

Pengumpulan data wawancara ini dilakukan dengan diadakannya tanya jawab kepada pihak yang secara langsung berhubungan dengan sistem pelaporan data NTE, yakni teknisi lapangan serta pihak administrasi NTE.

c. Studi Pustaka

Pengumpulan literatur yang berhubungan dengan penelitian baik dari buku, Jurnal, eJurnal dan literasi lain. 


\section{HASIL DAN PEMBAHASAN}

\section{Tahap Analisis}

Dari hasil analisis pada prosedur sistem berjalan, didapatkan spesifikasi kebutuhan untuk merancang aplikasi mobile web sebagai berikut:
A. Halaman Teknisi

A.1. Teknisi melakukan Login dengan memasukan Username dan Password

A.2. Teknisi Input Berita Acara

A.3. Teknisi Cek Status Berita Acara

B. Halaman Admin

B1. Admin melakukan login dengan memasukan Username dan Password

B2. Admin merubah status berita acara

B3. Admin cetak laporan berita acara

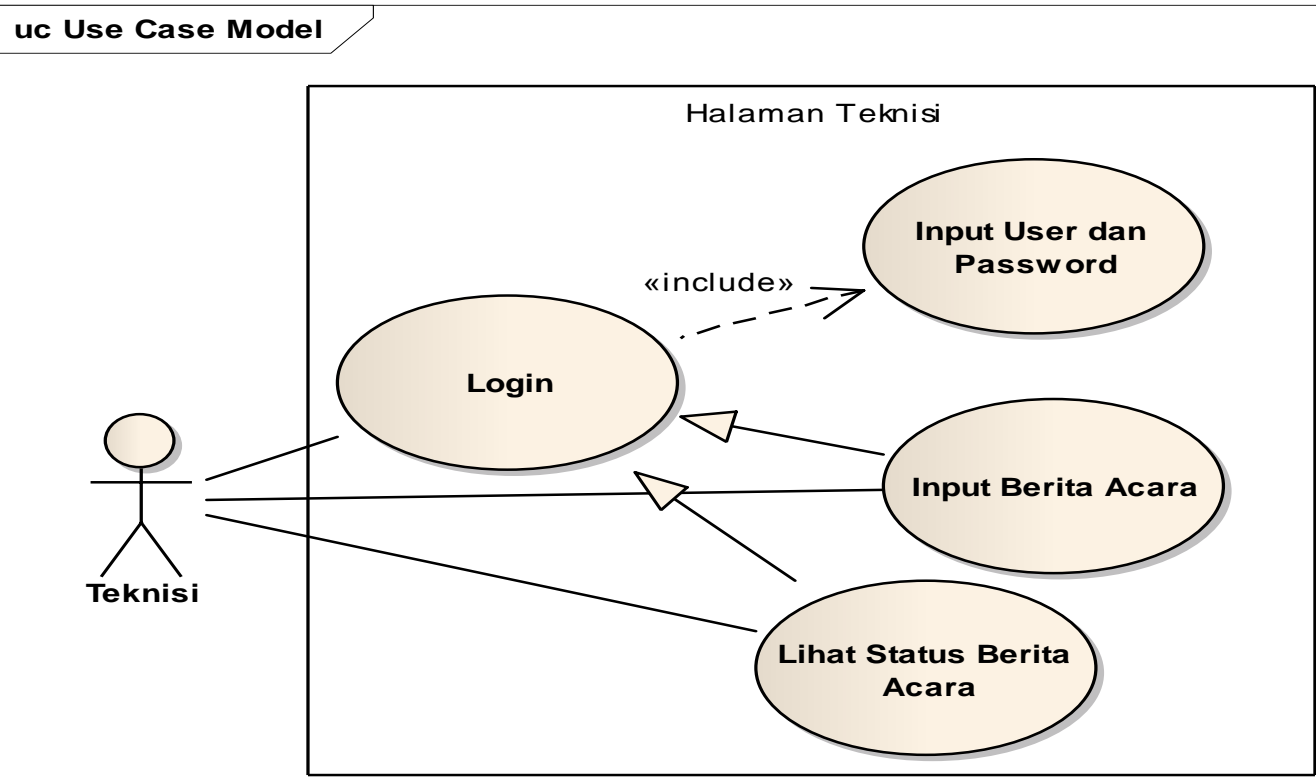

Gambar 1. Use Case Diagram Halaman Teknisi

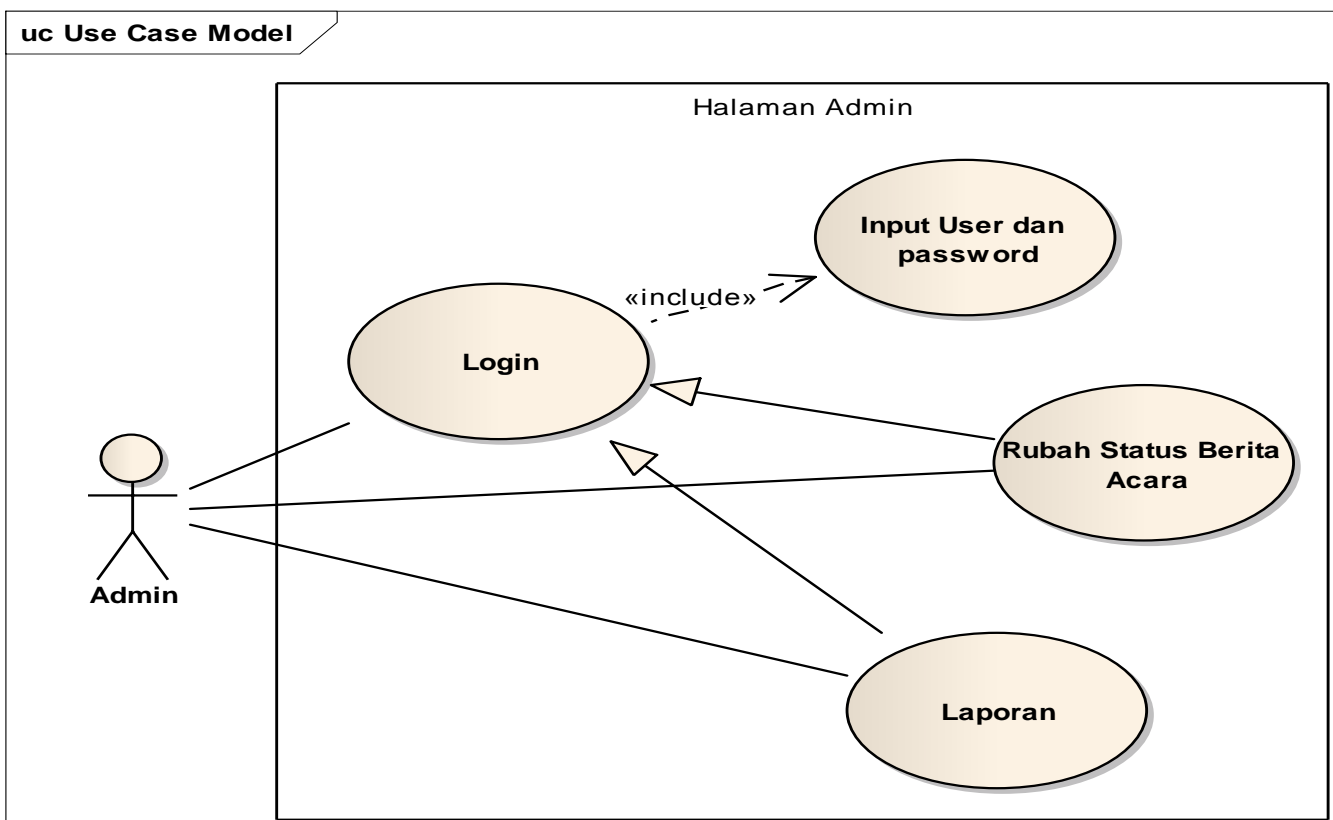

Gambar 2. Use Case Diagram Halaman Admin 


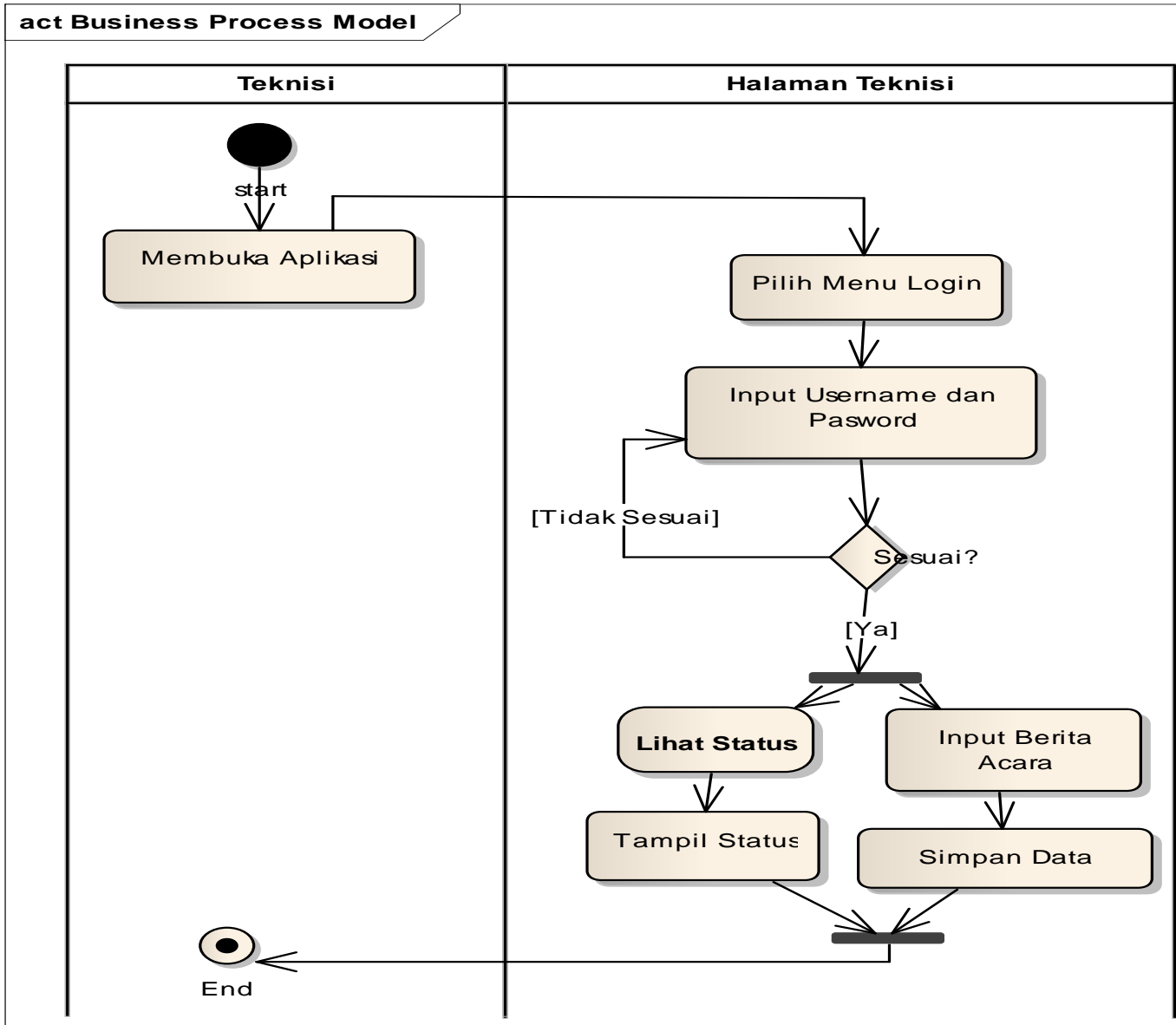

Gambar 3. Activity Diagram Halaman Teknisi

\section{act Aktiv ity Admin}

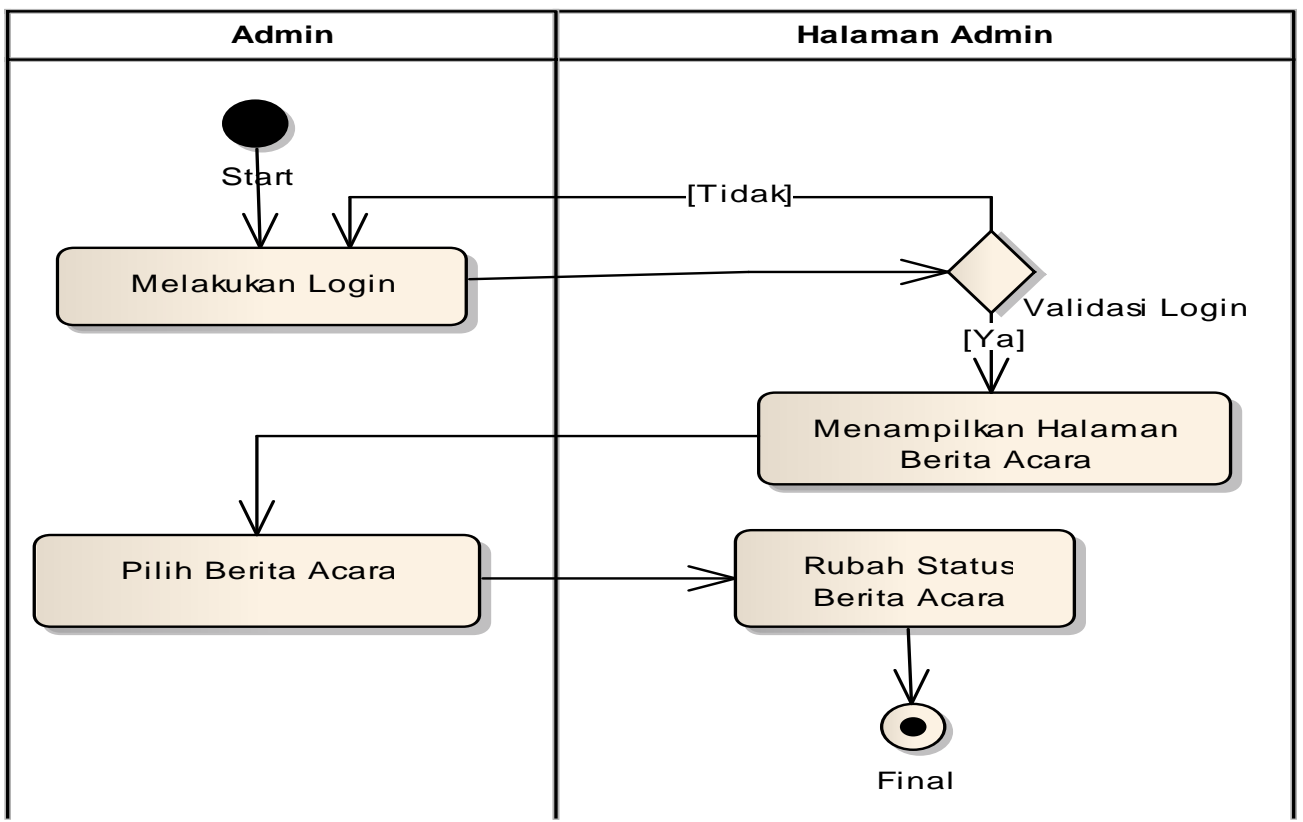

Gambar 4. Activity Diagram Rubah Status Berita Acara Halaman Admin 
act Activity Cetak Laporan

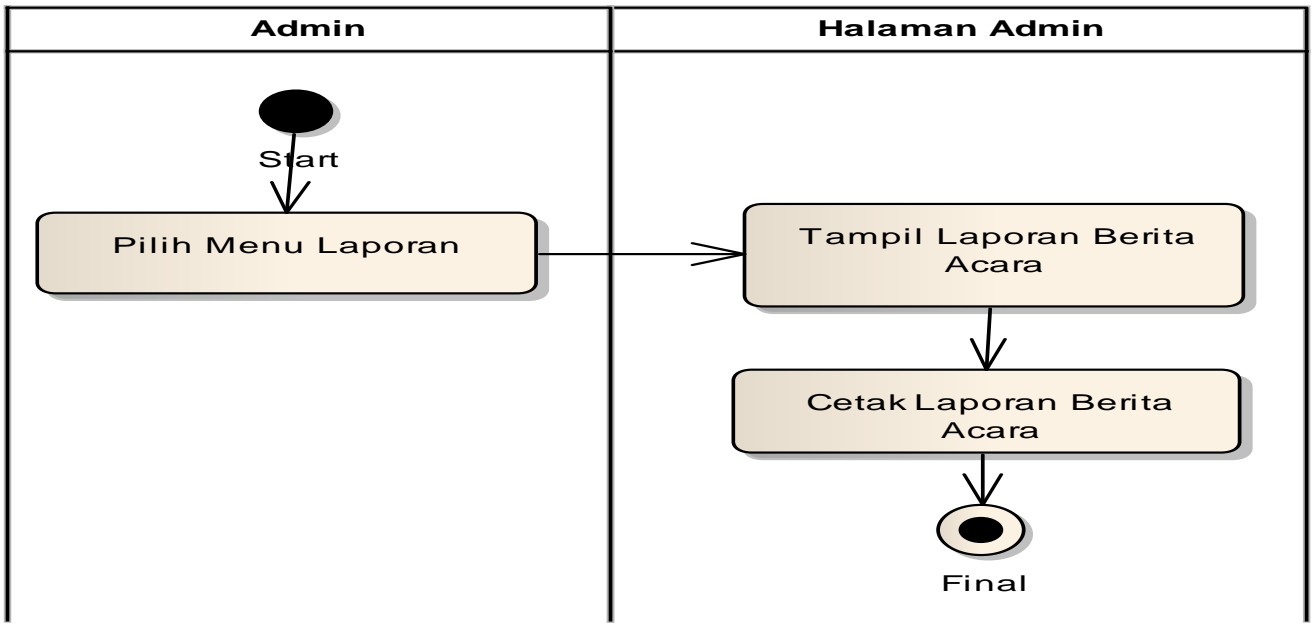

Gambar 5. Activity Diagram Menu Laporan Halaman Admin

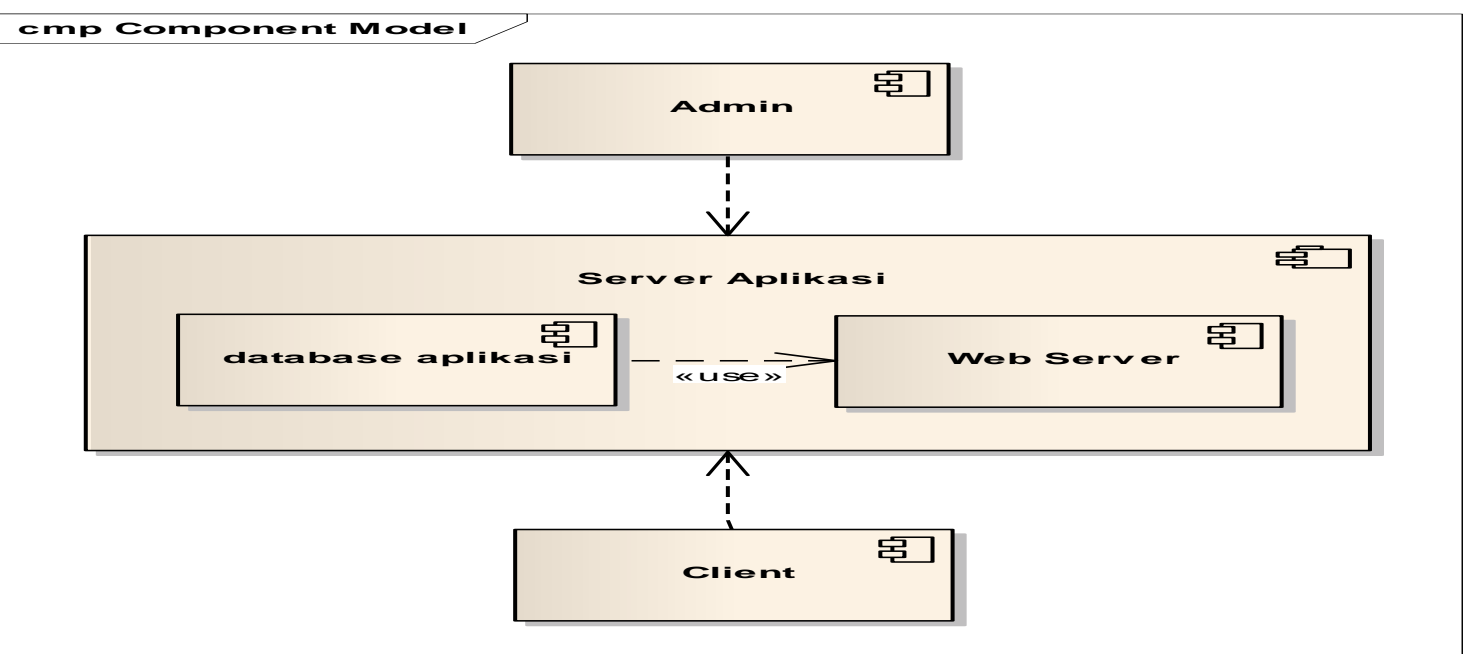

Gambar 6. Component Diagram

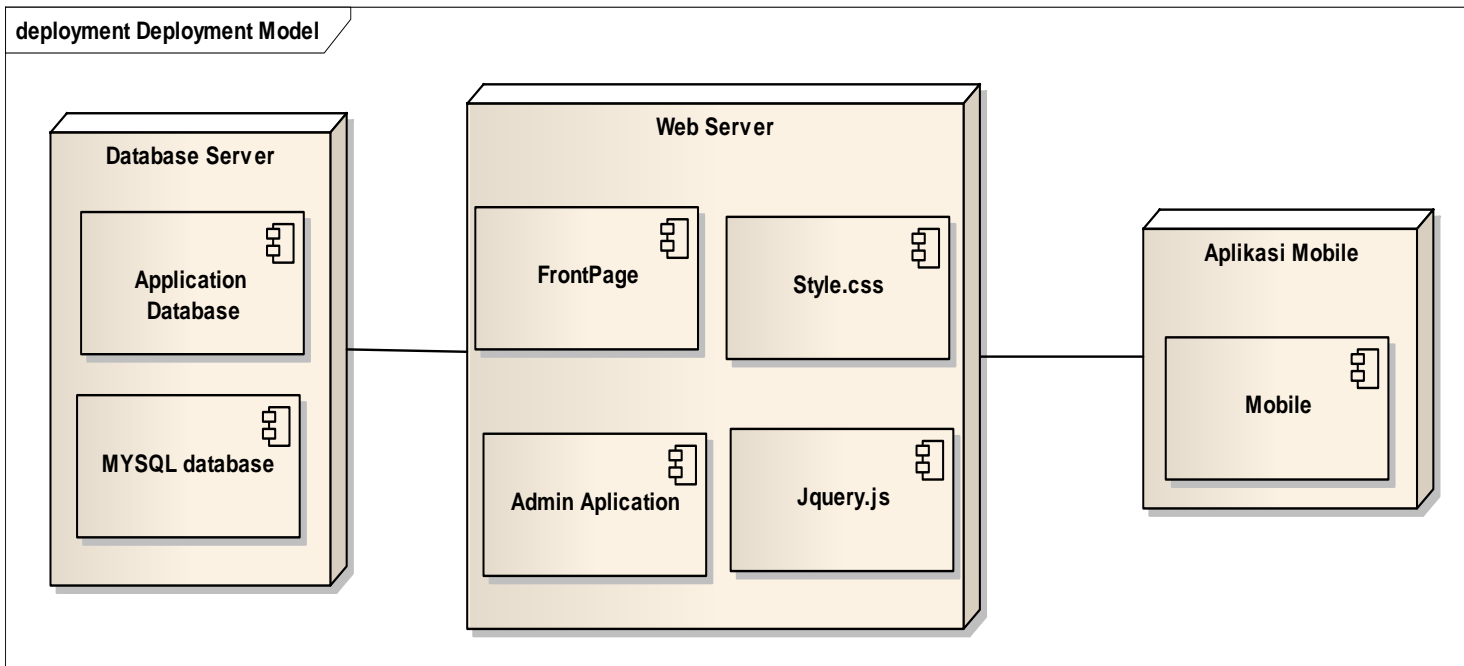

Gambar 7. Deployment Diagram 


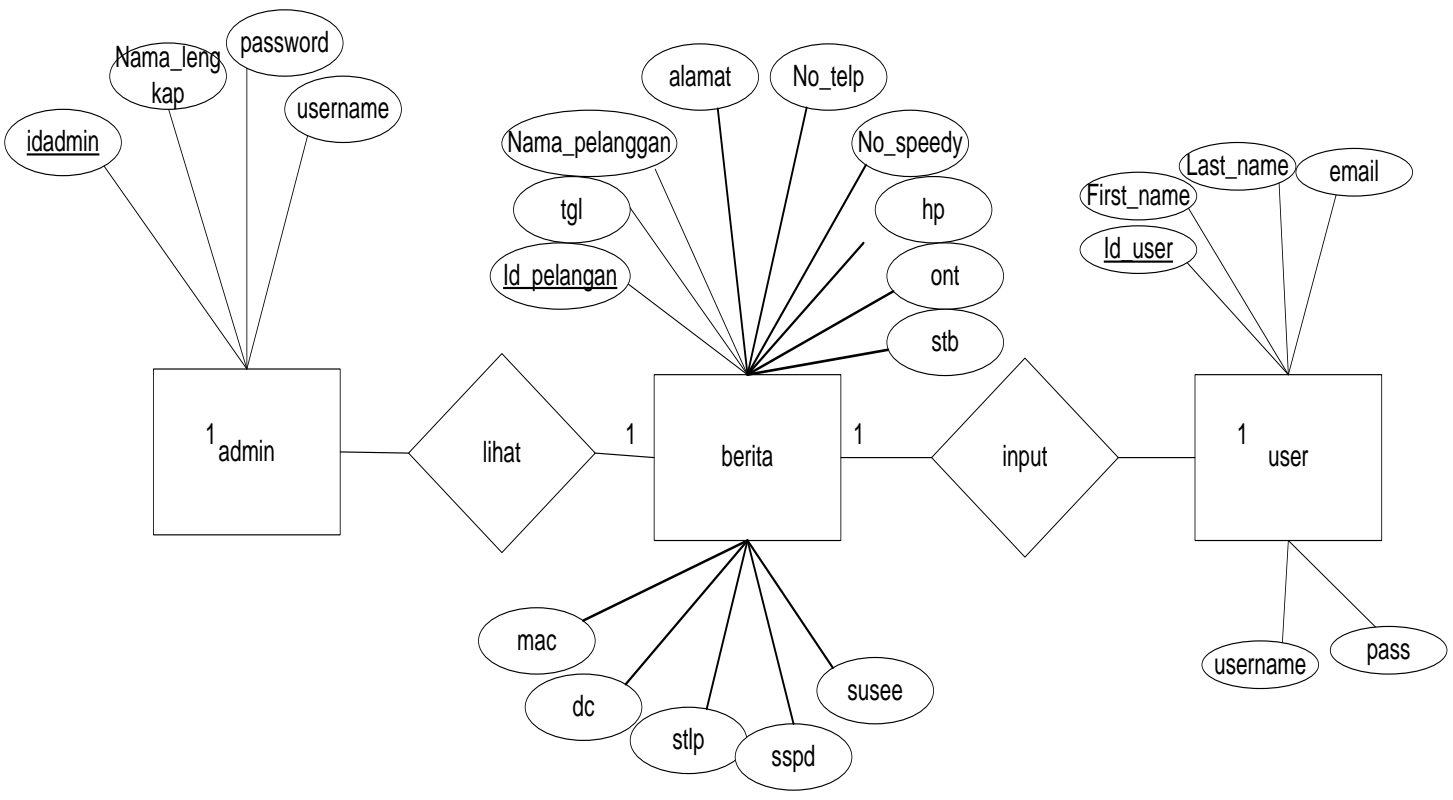

Gambar 8. Entity Realtionship Diagram

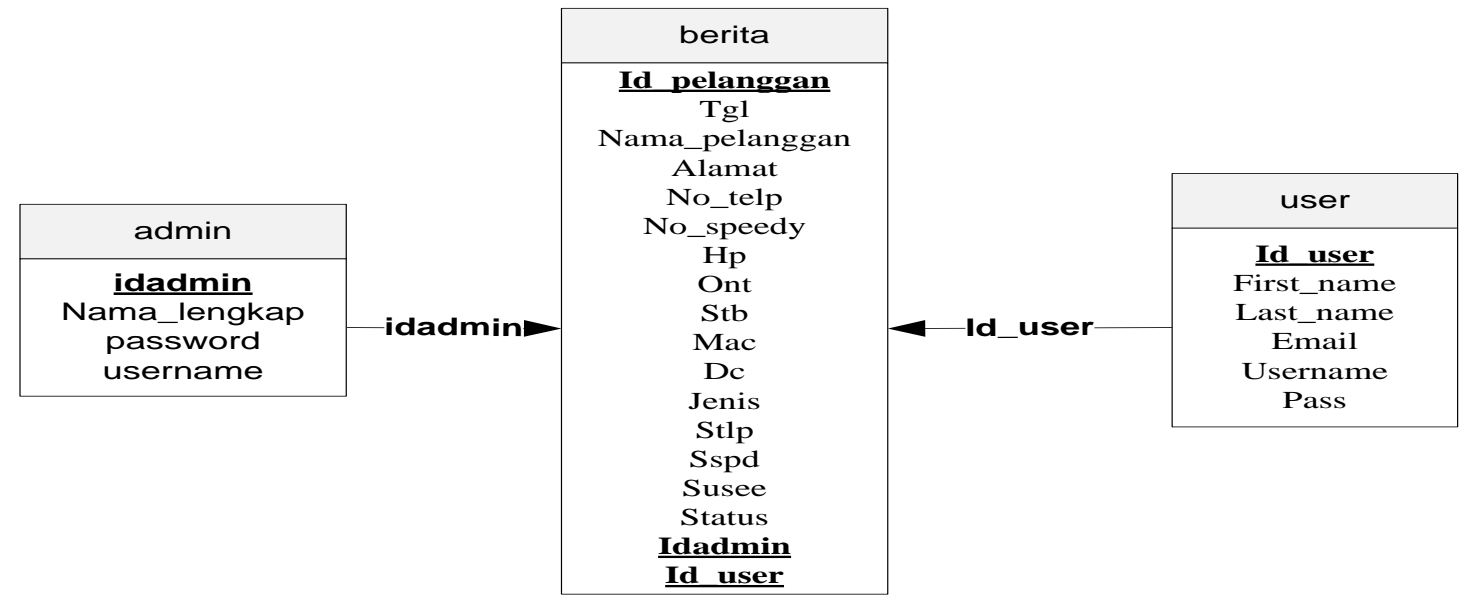

Gambar 9. Logical Record Structure

Implementasi Rancangan Antar Muka

1) Halaman Login

Halaman ini berfungsi untuk masuk ke dalam sistem web server NTE

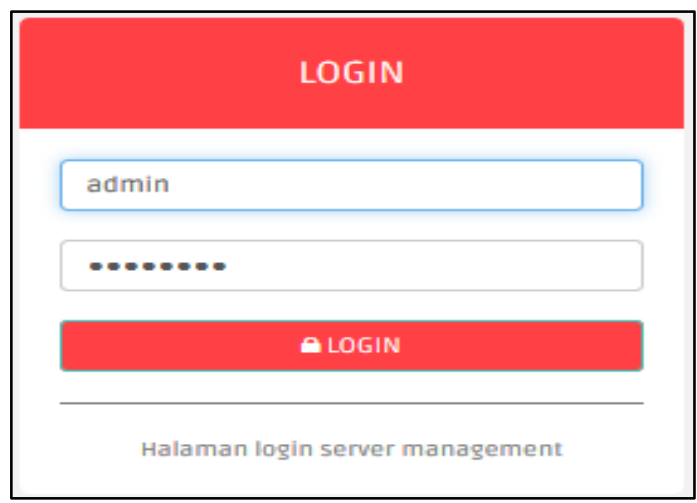

Gambar 10. Halaman Login Web Server NTE
2) Halaman Utama

Halaman ini merupakan halaman utama web server pengelolaan data berita acara NTE.

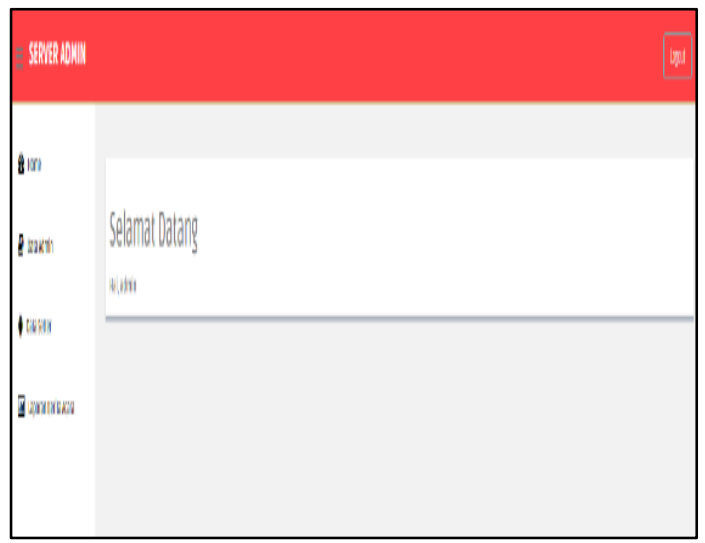

Gambar 11. Halaman Utama 
3) Halaman Admin

Halaman ini berfungsi untuk mengatur pengguna yang dapat mengelola halaman admin.

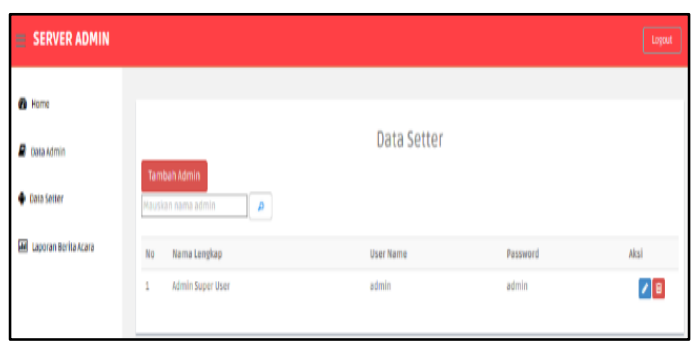

Gambar 12. Halaman Admin

4) Halaman Data Setter

Halaman ini berfungsi untuk mengelola data pemasangan dan pencabutan NTE.

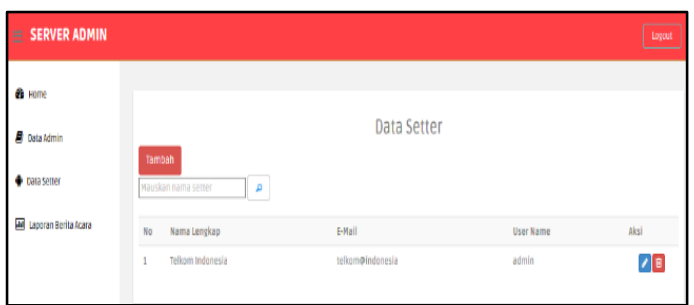

Gambar 13. Halaman Data Setter

5) Halaman Laporan

Halaman ini berfungsi untuk melihat laporan pemasangan dan pencabutan NTE secara berkala.

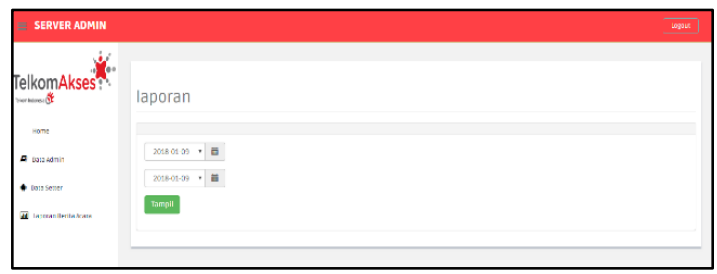

Gambar 14. Halaman Laporan

6) Halaman Login Aplikasi Mobile

Halaman ini berfungsi untuk masuk kedalam sistem di aplikasi mobile oleh teknisi di lapangan.

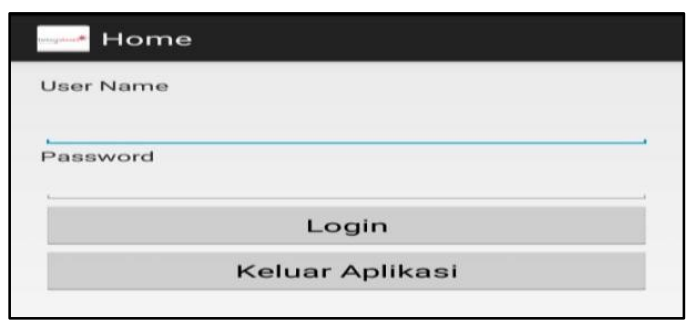

Gambar 15. Halaman Login Aplikasi Mobile
7) Halaman Utama Aplikasi Mobile

Halaman ini merupakan tampilan utama dari aplikasi mobile yang digunakan oleh teknisi NTE di lapangan.

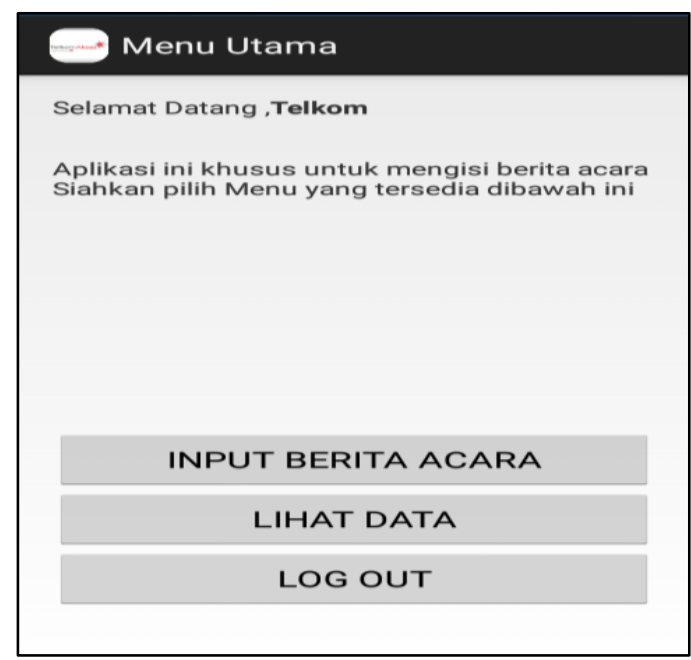

Gambar 16. Halaman Utama Aplikasi Mobile

8) Halaman Input Berita Acara

Halaman ini berfungsi untuk memasukkan berita acara pemasangan dan pencabutan instalasi NTE oleh petugas lapangan.

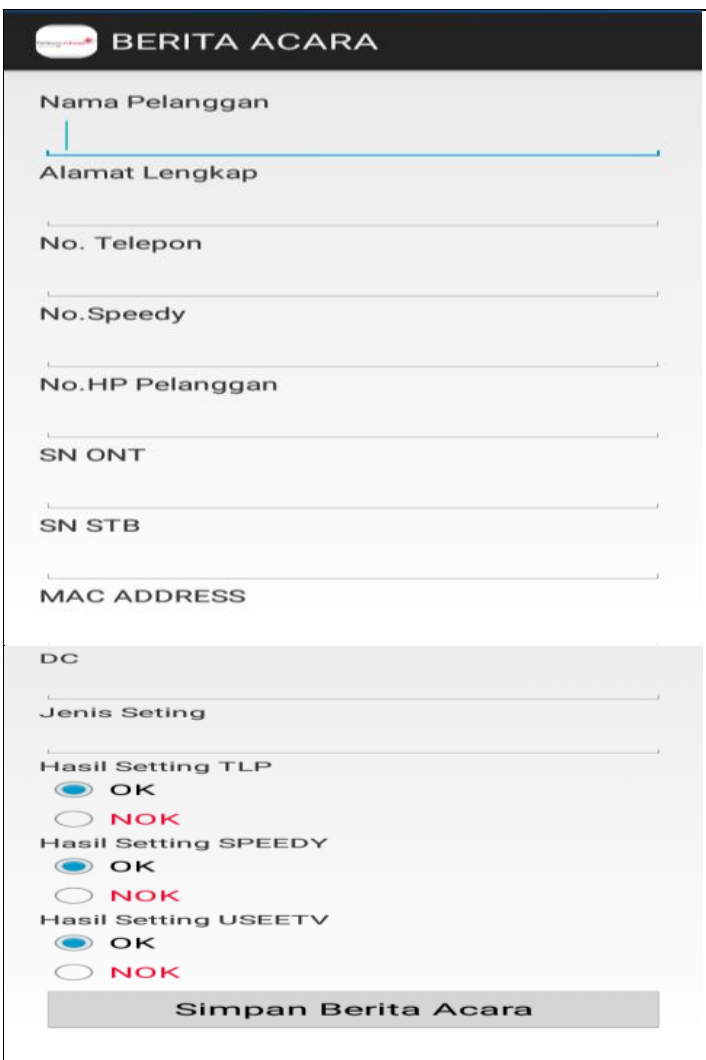

Gambar 17. Halaman Input Berita Acara 
9) Halaman Lihat Data

Halaman ini berfungsi untuk melihat data yang telah dimasukkan sebelumnya pada menu Input Berita Acara.

\section{Tampil data}

Nama : Tata

Alamat : cijalingan

Hasil Setting

Hasil Setting Telepon : OK

Hasil Setting Speedy : OK

Hasil Setting Usee : OK

Validitas

OK

Nama : Ariska

Alamat : cibalung

Hasil Setting

Hasil Setting Telepon : NOK

Hasil Setting Speedy : OK

Hasil Setting Usee : OK

Validitas

NoK

Gambar 18. Halaman Lihat Data

\section{KESIMPULAN}

Penerapan aplikasi mobile android untuk pelaporan data berita acara oleh teknisi di lapangan memudahkan bagian administrasi dalam mengelola data pemasangan dan pencabutan NTE. Bagian teknisi tidak perlu lagi untuk bertemu langsung dengan bagian administrasi hanya untuk menyerahkan berita acara NTE. Selain itu, pelaporan data NTE akan lebih cepat, lebih mudah untuk dikelola karena data dari teknisi langsung terintegrasi dengan web server di kantor PT. Telkom Akses.

\section{REFERENSI}

Agustina, R., Suprianto, D., \& Muslimin, I. (2017, Desember). Analisis Perancangan Pemesanan Makanan Menggunakan Smartphone Berbasis Android. STIKI Informatika Jurnal (SMATIKA Jurnal), 7(2), 26-30. doi:https://doi.org/10.32664/smatika.v7i0 2.154

Alam, N., \& Herman. (2018). Aplikasi Sistem Respon Cepat Masyarakat Berbasis Mobile Dalam Penanganan Kondisi
Darurat. Masyarakat Telematika Dan Informasi : Jurnal Penelitian Teknologi Informasi dan Komunikasi, 9(2), 143-150. doi:http://dx.doi.org/10.17933/mti.v9i2.12 6

Arfida, S., Amnah, \& Wibowo, H. (2018, April). Pemanfaatan Teknologi Android Terhadap Penyebaran Guru Bersertifikasi Tingkat Sekolah Dasar Negeri Provinsi Lampung. JUPITER (Jurnal Penelitian Ilmu dan Teknologi Komputer), 10(1), 18. Diambil kembali dari https://jurnal.polsri.ac.id/index.php/jupiter /article/view/763

Irsan, M. (2015). Rancang Bangun Aplikasi Mobile Notifikasi Berbasis Android Untuk Mendukung Kinerja Di Instansi Pemerintahan. JUSTIN (Jurnal Sistem dan Teknologi Informasi), 3(1), 115-120. Diambil kembali dari http://jurnal.untan.ac.id/index.php/justin/a rticle/view/9984

Munggaran, A. P., \& Hidayatulloh, T. (2015, Maret). Penerapan Algoritma C4.5 Untuk Diagnosa Penyakit Diare Pada Anak Balita Berbasis Mobile. Swabumi, II(1), 47-58.

doi:https://doi.org/10.31294/swabumi.v2i 1.1960

Nur'Ainun, Hartono, \& Jimmy. (2017). Perancangan Aplikasi Mobile Repository Skripsi (Skripsi Alumni Mahasiswa) STMIK IBBI Medan Berbasis Android. Jurnal Ilmiah Core IT : Community Research Information Technology, 5(2), 18-27. Diambil kembali dari http://www.ijcoreit.org/index.php/coreit/a rticle/view/12

Simalango, U., Huda, A., \& Dwiyani, N. (2018). Rancang Bangun Aplikasi Multimedia Interaktif Mobile Learning. Jurnal Vokasional Teknik Elektronika dan Informatika, 1-6.

Wibowo, A., Afrian, R., Bahri, S., Hidayatulloh, T., \& Wajhillah, R. (2018, Maret). InfoTekJar: Jurnal Nasional Informatika dan Teknologi Jaringan, 2(2), 130-134. doi:https://doi.org/10.30743/infotekjar.v2i 2.267 